Tények és vélemények a kritikai geográfiáról , a 3. Nemzetközi Kritikai Geográfiai Konferenciáról

Tér és Társadalom 17. évf. 2003/2. 113-116. p.

TÉT XVII. évf. 2003 - Tények és vélemények a kritikai geográfiáról

113

\title{
KRITIKAI POLITIKAI GAZDASÁGTANOK: VÁROSOK, RÉGIÓK ÉS A NEMZETKÖZI GAZDASÁG
}

\author{
(Critical Political Economies: Cities, Regions and the \\ International Economy)
}

\section{ANDERS LUND HANSEN}

„A kritikai földrajz terei" címü, elsô plenáris ülés egyik érdekes témája a társadalomtudományokon belül megfigyelhetó angol-amerikai hegemóniával foglalkozott. Kelet-Európa és a ,nyugat” közötti nemzetközi „,együttmúködés” hosszú idő óta nem az egyenlö felek közötti partnerséget jelenti. A probléma megértésének kulcsa a munkamegosztás. Jellemző módon a keleti partner végzi el a munka nehezét, ám a nyugati partner aratja le a munka gyümölcsét azzal, hogy az eredményeket úgynevezett „nemzetközi” (angol-amerikai) tudományos folyóiratokban teszi közzé (Timár Judit). Az angol-amerikai hatalom összefüggéseit az úgynevezett nemzetközi (angol-amerikai) folyóiratokból hiányzó földrajzi pluralitáson keresztül vizsgálták (Kirsten Simonsen).

A konferencia szervezői is tudatában voltak az angol-amerikai hegemóniának, hiszen a programot két ország képviselőinek előadásai és szekcióelnökségei dominálták: az Egyesült Királyság és az Egyesült Államok képviselői együtt a program több mint egyharmadáért voltak felelősek. A témavezetök és az ülések vezetői igyekeztek minden résztvevőt bevonni a vitákba, figyelembe véve azt, hogy a résztvevők nagy része második vagy harmadik tanult idegen nyelven dolgozott. Nehéz megmondani, hogy sikeresen hajtottuk-e végre feladatunkat. Én úgy érzem, hogy mindenki igyekezett legyözni a többnyelvü kommunikáció akadályait, amely szintén alapvető fontosságú, ha valóban nemzetköziek szeretnénk lenni.

A nyolcadik téma, „Kritikai politikai gazdaságtanok: városok, régiók és a nemzetközi gazdaság" nagyon érdekes programot kínált. Háború, terrorizmus, 2001. szeptember 11. utáni események, imperializmus, poszt-kolonializmus, globalizáció, természet, kizsákmányolás, kirekesztés és befogadás, társadalmi nem, hatalom, határok, identitás és aktivizmus, csak egy kis ízelítő a konferencia során megvitatott témák széles körébỏl.

Az „Újragondolt Globalizáció" panelban többek között a globalizáció térszerkezete (Ben Derudder), a világvárosi szereplö-hálózatok (Richard Smith), a törzsi kultúrák túlélésének problémája (Mateusz Wiercinski), a globális város peremterületei és a Tokyo-i kis gyáriparosok (Paul Waley) keruiltek megvitatásra.

A „Városi és regionális átalakulás a poszt-szocialista országokban” címủ tanulságos szekció megvitatta a kapitalizmus bevezetésének kudarcát általában (Dragos Simadan), a magyar városi térben megjelenö konfliktusokat (Nagy Erika), a munka és 
Tények és vélemények a kritikai geográfiáról , a 3. Nemzetközi Kritikai Geográfiai Konferenciáról Tér és Társadalom 17. évf. 2003/2. 113-116. p.

közösség kérdéseit a poszt-szocialista Lengyelországban (Alison Stenning). A konferencia során egy panelvita vizsgálta a kelet-közép-európai és az ázsiai demokratizálódási folyamat és piacgazdasági átmenet közötti hasonlóságokat és különbségeket. „A városfejlesztési stratégiák kritikai távlatai” címú szekció a modern nyugati városokon belüli egyenlötlenségekkel foglalkozott azon kapcsolatok és tér-idỏ pályák alkotóelemeinek és folyamatos kialakulásának tanulmányozásán keresztuil, amelyek hozzájárulnak a szubjektum „Multipolis”-on belüli létéhez (Edward Huijbens). A ,városi térháborúk” (Anders Lund Hansen) témája szintén arra koncentrált, hogy a városok közötti globális szintủ verseny hogyan vezet a városi léptékủ egyenlötlen fejlődéshez és térháborúkhoz. Az érvelés alapja az volt, hogy a térháborúk globális-városi kapcsolatrendszere nagyszerú megközelítési módot kínál az egyenlötlen földrajzi fejlődés és a városi lépték létrehozása mögött rejlő folyamatok megértéséhez. Az utolsó előadás a dél-afrikai „,városfejlesztési stratégiákról” szólt (Jenny Robinson), hangsúlyozva az alternatív városfejlesztési stratégiák lehetséges alkalmazási területét.

Nagyon élénk vita bontakozott ki a résztvevők között a kutató szerepéröl: Hogyan tudjuk az egyenlőtlen földrajzi fejlődésről és az átlagemberrel szembeni terror tájairól szerzett tudásunkat aktívan felhasználni? Véleményem szerint az ülés minden szekció modellje lehetne. A siker a kiválóan felkészült és energikus levezető elnöknek (Jenny Robinson) volt köszönhetö. Ezt a mexikói konferencia szervezőinek is figyelmébe ajánlom.

A „Szegregáció, polarizáció és városi szegénység" címú szekció során a területhasználati zónák kialakítása [zoning] és a társadalmi-térbeli szegregáció Campinasban (Paolo de Brito Soares), a szöuli társadalmi polarizáció (Seok-Hoe Yim), az iráni városi szegénység csökkentését célzó stratégiák (Rahim Rahnema) és a romániai szegénység elleni regionális fejlesztési stratégiák (Christoph Waack) kerültek megvitatásra. Nagyon érdekes volt meghallgatni az esettanulmányokat, de az átfogó kép igen összetett. Ez részben a rossz levezető elnöknek (a szerző) volt köszönhető, akinek (próbálkozásai ellenére) soha nem sikerült betartatni a tanulmányok szóbeli előadására szánt időt, így a szekció során nem volt lehetőség a résztvevők közötti összefüggő vitára.

A konferencia fénypontja a "Városi kultúra és a városvezetés új távlatai” címü szekció volt. Az egyik előadás azt mutatta be, hogyan használják fel a belső befektetések ösztönzésében az ,imidzset, a képviseletet és az önkormányzást” (Martin Bickl). Egy másik a „közép-skandináviai határokon átnyúló oktatási rendszerek”-et mutatta be (Hans W. E. Thorsen), jól szemléltetve azt, hogy oktatási hálózataikon keresztül a perifériák hogyan tudják felvenni a harcot az egyenlőtlen földrajzi fejlödés jelenlegi formái ellen. A „mindennapi részvétel”-röl szóló előadás (Esben Holm Nielsen) azt mutatta be, hogyan tudnak az új társadalmi-térbeli stratégiák hozzájárulni a várospolitikák új területeinek létrejöttéhez. A szerző véleménye szerint a sportegyesületek a „mindennapi résztvevő" olyan csoportját alkotják, amelyet be kell vonni a városvezetési hálózatokba, ha alternatív városi tájakat akarnak megvalósítani. 
Tények és vélemények a kritikai geográfiáról , a 3. Nemzetközi Kritikai Geográfiai Konferenciáról Tér és Társadalom 17. évf. 2003/2. 113-116. p.

TÉT XVII. évf. 2003 匹 2 Tények és vélemények a kritikai geográfiáról

115

Az Egyesült Államok „Népföldrajzi projektje” (Don Mitchell) ebben az évben is a konferencia egyik folyamatosan megvitatott kérdése volt. A projekt célja a kritikai és radikális földrajz népszerüsítése és az aktivista csoportok és a geográfusok közötti kapcsolatok létrehozása. A projekt azt szeretné megvilágítani, hogy „,a mindennapi életet olyan bonyolult hatalmi kapcsolatok strukturálják, amelyek alapvetöen földrajzi természetủek", és szeretné ezt a földrajzi tudást a társadalmi és gazdasági igazságosságért vívott harcban felhasználni. Az ilyen kezdeményezések kulcsfontosságúak abban a harcban, amelyet azért vívunk, hogy a Föld egy igazságosabb hely legyen.

A népföldrajzi projekt egyik leggondolatébresztöbb kerekasztal-vitája: a „Népföldrajz szeptember 11-röl és szeptember 11. után. Hogyan beszélhetünk a terror földrajzáról, hogy ezzel is elösegítsük az igazságért vívott harcot?" New York-ban a terrorizmus tája tisztán olvasható, ha meglátogatjuk a "ground zero"-t. Ebben az összefüggésben azonban a vizsgálat tárgya az volt, hogy 2001. szeptember 11. után (illetve október 7., az afganisztáni háború kirobbanása után) a nyilvános terekben hogyan szabályozták az emberek tevékenységét. Az előadók (Cindi Katz, Don Mitchell, Neil Smith) beszámoltak arról, hogyan kezelte a helyzetet Giuliani polgármester New Yorkban. Amerikai összefüggésben tekintve, a nép alapvetö jogait csorbították azzal, hogy korlátozták a szabad mozgást és a nyilvános beszédet. Az átlagemberek elleni terror azonban nem olyan új jelenség, amely 2001. szeptember 11. és október 7. nyomában jelent meg. Guiliani neo-liberális „zéró tolerancia” politikája csak még jobban kiterjedt, mivel szeptember 11. és október 7. eseményeit a már folyamatban lévő tendenciák indoklására használták.

Ez után az indítás után az ülés mintegy ötven résztvevője között nagyon élénk vita bontakozott ki. A világ minden tájáról érkeztek példák a problémára. Sok példát hoztak fel arra, hogyan jelent meg a „zéró tolerancia” politikája különféle nemzetí és városi összefüggésekben. Egy másik kapcsolódó téma az új szélsőjobboldal térnyerése Európában. A már meglévő politikai tendenciákra alapozva a mozgalom kihasználta a 2001. szeptember 11. utáni iszlám ellenességen és idegengyülöleten alapuló pánikot, hogy kialakítsa az „idegenek” elleni demagóg retorikáját, főleg a harmadik világból és az iszlám országokból érkezett bevándorlók ellen. Ez a primitív stratégia sikerhez segítette ezeket a mozgalmakat a nemzeti választásokon (legszembetűnőbben Ausztriában, Dániában és Hollandiában). Összességében az ülés az átlagemberek ellen irányuló terror új tájait vagy topográfiáit (Cindi Katz) mutatta be. Ezeket a tájakat fel kell térképeznünk, és harcolni kell ellenük.

Természetesen nagyon sok vélemény és politika jelent meg a békéscsabai konferencián általánosságban, és sokfajta vélemény volt magáról a konferenciáról is (javarészt nagyon pozitív). Összességében, optimista hozzáállást érzékeltem a kritikai geográfiai konferencia mint a kritikai gondolatok értékes fóruma felé, ahol az alternatív földrajzról szóló gondolatok születnek.

Béke, remény, szeretet! 
Tények és vélemények a kritikai geográfiáról , a 3. Nemzetközi Kritikai Geográfiai Konferenciáról

Tér és Társadalom 17. évf. 2003/2. 113-116. p.

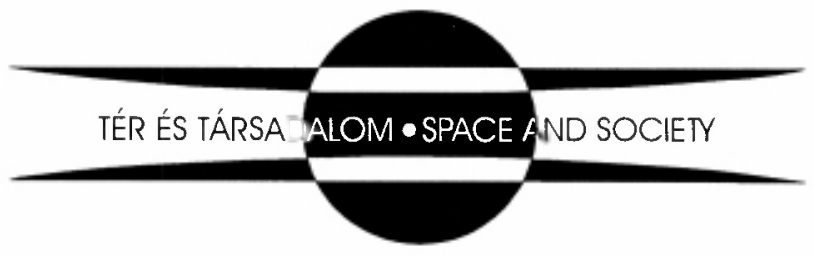

